\title{
Study on the incidence of Salmonella enteritidis in poultry and meat samples by cultural and PCR methods
}

\author{
Putturu Ramya, Thirtham Madhavarao, Lakkineni Venkateswara Rao \\ College of veterinary science, \\ Sri Venkateswara Veterinary University, Rajendranagar, Hyderabad - 30, Andhra Pradesh, India \\ Corresponding author: Putturu Ramya, e-mail: puttururamya@gmail.com \\ Received: 28-01-2012, Accepted: 18-03-2012, Published Online: 19-06-2012 \\ doi: $10.5455 /$ vetworld.2012.541-545
}

\begin{abstract}
Aim: To study the incidence of S.enteritidis in poultry and meat samples by cultural and PCR methods. Materials and Methods: A total of 130 samples ( 25 each of chicken, mutton, poultry faeces, cloacal samples and 10 each of liver, spleen and kidney) collected from different sources were subjected to cultural and PCR methods for the presence of Salmonella and Salmonella enteritidis. Primers for invA and sefA gene were used for Salmonella and S.enteritidis respectively.

Results: Out of 130 samples, 87 were positive for Salmonella spp. i.e. chicken-16(64\%), mutton-12(48\%), faeces-23(92\%), cloacal swabs-23(92\%), liver-5(50\%), spleen and kidney samples-4(40\%) each by PCR methods, whereas 77 were positive by cultural method i.e. chicken-14(56\%), mutton-10(40\%), faeces-22(88\%), cloacal swabs-21(84\%), liver-4(40\%), spleen and kidney-3(30\% each). Out of 87 positive for Salmonella by PCR method, 59(chicken-12, mutton-7, faeces-17, cloacal swabs-15, liver-3, spleen-2, kidney-3) were positive for S.enteritidis. High incidence of S.enteritidis (68\%) in all the above samples are indicative of unhygienic conditions in poultry farms. Selective enrichment with Rappaport-Vassilidias (RV) broths and Tetrathionate (TT) broths were superior over Selenite-F (SF) and Selenite cysteine (SC) broths.

Conclusions: High incidence of S.enteritidis was seen in most of poultry samples like chicken, kidney, liver and it's faeces than mutton, which was indicative of contamination of S.enteritidis is more prevalent in poultry farms.

Keywords: Cultural, Incidence, PCR, Salmonella, Salmonella enteritidis.
\end{abstract}

\section{To cite thisarticle:}

Ramya P, Madhavarao T, Rao LV (2012) Study on the incidence of Salmonella enteritidis in poultry and meat samples by cultural and PCR methods, Vet World, 5(9): 541-545, doi: 10.5455/vetworld.2012.541-545

\section{I ntroduction}

Salmonella is one of the most important pathogenic genera implicated in food borne bacterial outbreaks and diseases both in developed and developing countries and constitute an important public health problem [1]. Despite global improvements in public health facilities, a marked increase in human salmonellosis has been reported in many countries including the European Union [2]. Outbreaks of Salmonella have been associated with wide variety of foods especially those of animal origin [3]. In many countries human salmonellosis is mainly due to consumption of eggs followed by poultry, pork, beef, and dairy products [4].

S.enteritidis is the main cause of food borne salmonellosis [5] and during the last $20 \mathrm{y}$, it has been a major causative agent of foodborne gastroenteritis in humans [6]. There is increasing evidence suggesting that the main source of human pathogens are poultry products especially eggs [7]. The symptoms in humanbeings includes diarrhoea, nausea, abdominal pain, mild fever, chills, vomition, prostration, headache, malaise etc. and the diarrhoea varies from thin vegetable soup like stools to a massive evacuation with accompanying dehydration [8].

The number of organisms, to be swallowed inorder to cause infection is rather small that is fewer than 10 [9] and it is a must for the livestock products to be tested for the presence of Salmonella due to it's potentially low infective dose [10]. The detection of Salmonella in foods is problematic due to presence of fewer number of organisms, larger number of competing microflora and due to injured organisms by different food processing methods [11]. The conventional culture method, which is routinely used for isolation of Salmonella is time consuming, laborious and may not be suitable for viable but non culturable (VBNC) [10].

To overcome this drawback, immunological and genetic detection methods have been developed [12]. PCR method is rapid, specific and sensitive method for the detection of food borne pathogens [13]. 
Study on the incidence of Salmonella enteritidis in poultry and meat samples by cultural and PCR methods

Table-1. Details of primers used in this study

\begin{tabular}{lclcl}
\hline Primer & Target Gene & Primer sequence & Amplification product (bp) & Reference \\
\hline Salm-3 & invA & 5'-GCT GCG CGC GAA CGG CGA AG-3' & 389 & Malorny et. al. [14] \\
Salm-4 & invA & 5'-TCC CGG CAG AGT TCC CAT T-3' & 389 & Malorny et. al. [14] \\
SefA2 & sefA & 5'-GCC GTA CAC GAG CTT ATA GA-3' & 310 & Pan and Liu, [15] \\
SefA4 & sefA $^{\mathrm{b}}$ & 5'-ACC TAC AGG GGC ACA ATA AC-3' & 310 & Pan and Liu, [15] \\
\hline
\end{tabular}

In this study PCR method was used to detect Salmonella spp. and S.enteritidis targeting invA and sefA genes respectively.

\section{Materials and Methods}

A total of 130 different mutton and chicken related samples (25 samples each of mutton, chicken meat, chicken faeces, cloacal samples of poultry and 10 each of chicken liver, spleen and kidney) were collected from three retail markets and two slaughter houses (five replications each) in and around Hyderabad. The samples were collected in the sterile containers and transferred under cold conditions (with icepack) to the lab. Mutton, Chicken meat and chicken internal organs $(10 \mathrm{~g})$ samples were preenriched in $90 \mathrm{ml}$ of buffered peptone water (BPW) in individual sterile polythene bags homogenized thoroughly in a stomacher for 3-5 min and incubated at $37^{\circ} \mathrm{C}$ for $16 \mathrm{~h}$. Faeces and cloacal swabs were inoculated in BPW in test tubes $(50 \mathrm{ml})$ and incubated at $37^{\circ} \mathrm{C}$ for $16 \mathrm{~h}$. After preenrichment $1 \mathrm{ml}$ of each inoculum was transferred into selective broths like Tetrathionate (TT) broth, Selenite-F (SF), Selenite cysteine (SC) broths and 0.1 $\mathrm{ml}$ to Rappaport-Vassilidias (RV) broth, incubated at $42^{\circ} \mathrm{C}$ for $18 \mathrm{~h}$ (For SC broth, $37^{\circ} \mathrm{C}, 18 \mathrm{~h}$ ). The broth cultures were spread plated onto selective media agar plates like Xylose Lysine Deoxycholate agar (XLD), Bismuth Sulphite Agar (BSA), Brilliant Green Agar (BGA), Salmonella-Shigella Agar (SSA) and Hektoen Enteric Agar (HEA) and differential agar like MacConkey Agar. Petridishes were incubated at $37^{\circ} \mathrm{C}$ for $24 \mathrm{~h}$. The presumptive colonies of Salmonella were taken for further confirmation by biochemical tests like IMViC (Indole, Methyl red, Voges-Proskauer, Citrate), Triple sugar iron test, sugar fermentation tests, lysine decarboxylase, ONPG(ortho-nitrophenyl galactosidase).

All the enriched samples were subjected to PCR analysis for the presence of Salmonella spp. using primers specific to invA. The samples positive for Salmonella by PCR method were further examined for the presence of S.enteritidis strains using primers specific for sefA gene (Table1). Primers used in this study were obtained from Bangalore Genei.

S.enteritidis strain obtained from Microbial
Type Culture Collection (MTCC), Chandigarh was used as known positive strain in PCR analysis. About $1.5 \mathrm{ml}$ of enriched broths were taken in eppendorf tubes and bacteria were pelleted by centrifugation at $8000 \mathrm{rpm}$ for $10 \mathrm{~min}$ and the supernatant was discarded. Fifty $\mu l$ of sterile distilled water was added to the tubes and boiled in a water bath at $100^{\circ} \mathrm{C}$ for 10 min and immediately snap chilled to release DNA. Then centrifuged at $13,000 \mathrm{rpm}$ for $5 \mathrm{~min}$ and the supernatants containing DNA from respective samples were used as templates for PCR analysis.

Bacterial DNA amplification was done in $20 \mu \mathrm{l}$ reaction mixture containing $2 \mu \mathrm{l}$ of $10 \mathrm{x}$ Taq DNA polymerase buffer containing $100 \mathrm{mM}$ tris with $\mathrm{p}^{\mathrm{H}}$ 9.0, $500 \mathrm{mM} \mathrm{KCl}, 15 \mathrm{mM} \mathrm{MgCl}$ and $1 \%$ triton X-100), 2 $\mu \mathrm{l}$ of $10 \mathrm{mM}$ dNTP mix, $0.9 \mathrm{U} / \mu \mathrm{l}$ of Taq DNA polymerase (Genei), $2 \mu 1$ each of forward and reverse primer $(4 \mathrm{pmol} / \mu \mathrm{l})$ and $5 \mu \mathrm{l}$ of crude bacterial cell lysate. This mixture was made upto $20 \mu \mathrm{l}$ using molecular grade water. Amplification was done in thermal cycler following standardized conditions (Table-2).

Table-2. Cycling conditions

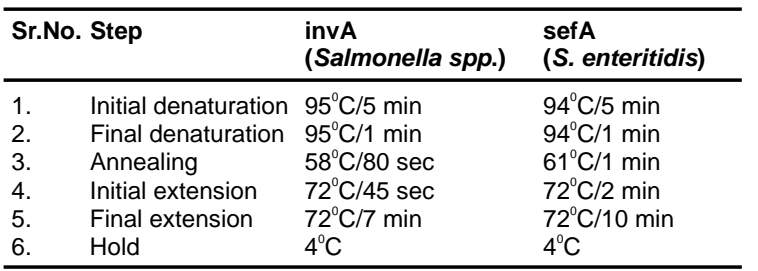

The amplified DNA fragments were resolved by agarose gel electrophoresis, stained with ethidium bromide $(0.5 \mu \mathrm{g} / \mathrm{ml})$ and visualized with an UV transilluminater (Fig. 1).

Spiking studies: To know the sensitivity of PCR method for S.enteritidis, homogenized chicken was inoculated at the rate of $250 \mathrm{cfu}, 25 \mathrm{cfu}, 2.5 \mathrm{cfu}$ and $0.25 \mathrm{cfu}$ per $10 \mathrm{~g}$ of chicken and transferred to preenrichment media i.e. $90 \mathrm{ml}$ of BPW, incubated at $37^{\circ} \mathrm{C}$ for $8 \mathrm{~h}$ and $16 \mathrm{~h}$. After incubation, inoculum transferred to selective broths like RV, TT, SF \& SC broths and incubated for 12 and $18 \mathrm{~h}$. The PCR and cultural testing were carried after $12 \mathrm{~h}$ and $18 \mathrm{~h}$ of incubation. 


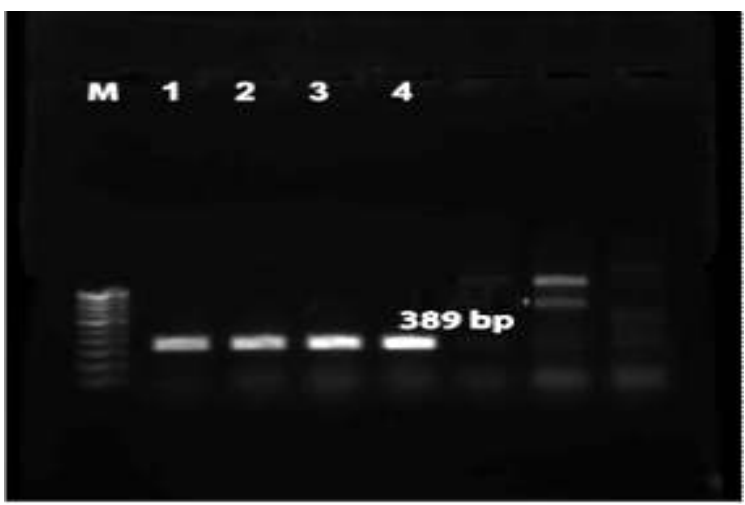

Figure-1. Results of chicken meat samples for invA Lane M: 100 bp DNA Ladder, 1,2,3,4: chicken meat samples showing positive results (Salmonella spp.)

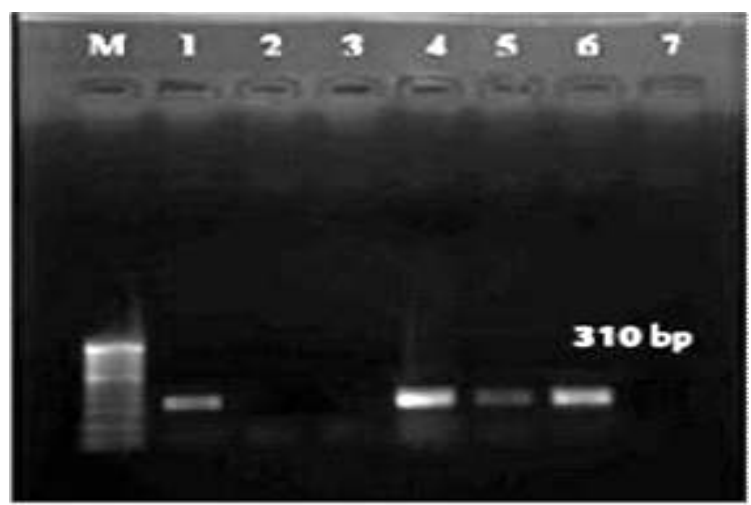

Figure-2. Results of chicken meat samples for SefA Lane M: 100 bp DNA Ladder, 1,4,5,6: chicken meat samples showing positive results (Salmonella spp.)

Table-3. Occurrence of Salmonella spp. and Salmonella enteritidis in mutton and chicken related samples

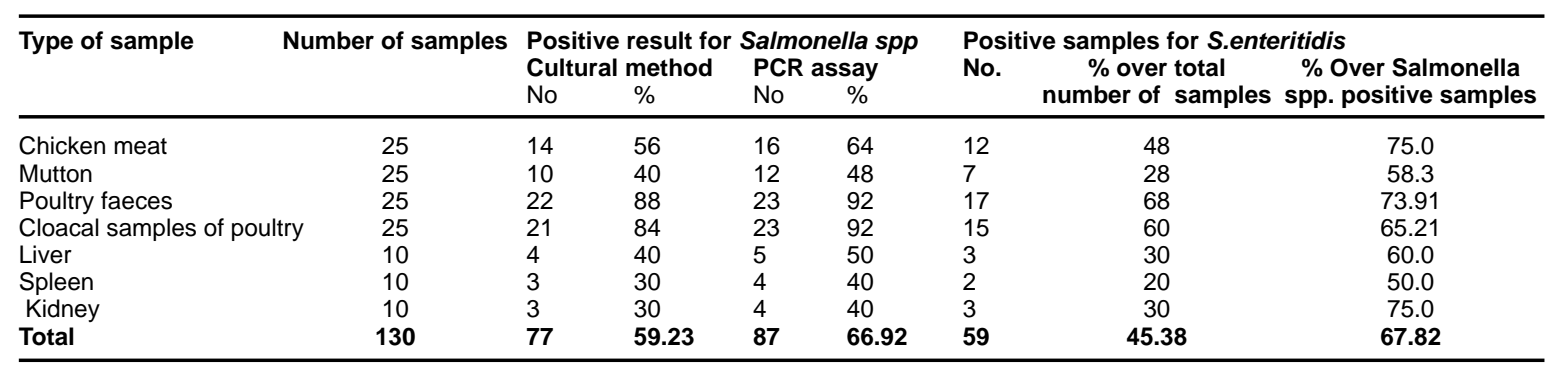

\section{Results and Discussion}

Out of 25 chicken meat samples, 14(56\%) were positive for Salmonella by cultural method and $16(64 \%)$ by PCR method (Fig. 1). Out of 16 PCR positives, 12 were positive for S.enteritidis by PCR (Fig. 2) which accounts to 48 and $75 \%$ over total number of samples and positive samples for Salmonella by PCR respectively (results are shown in Table:3). Similar results were reported by Hassanien et. al. [16]. Low incidence of Salmonella in chicken meat than the present study $(56 \%)$ by cultural method i.e. $40 \%, 26.3 \%, 18 \%$ and $6.79 \%$ were reported by Tavechio, [17]; Plummer et. al. [18]; Cortez et. al. [19] and Amini et. al. [20] respectively, whereas Blivet et. al. [21] reported higher incidence $(97.6 \%)$. The incidence of Salmonella by PCR method in the present study $(64 \%)$ was similar to the findings of Malkawi and Gharraibeh [22] and higher than the incidence $(36.5 \%)$ reported by Uyttendaele et. al. [23]. The incidence of S.enteritidis in the present study $(75 \%)$ by PCR was less than the incidence $(90 \%)$ reported by Wang et. al. [24] and higher than the incidence (5.6\% and $8 \%$ ) reported by Cortez et. al. [19] and Hassanien et.al. [16] respectively.

The high incidence of Salmonella spp. and
S.enteritidis in chicken might be due to not following hygienic methods in rearing, slaughtering and marketing.

Out of 25 mutton samples, 10(40\%) and $12(48 \%)$ were positive for Salmonella by cultural method and PCR methods. Out of 12 PCR positives, 7 were positive for $S$. enteritidis by PCR, which accounts to 28 and $58.3 \%$ over total number of samples and positive samples for Salmonella by PCR respectively. High incidence of Salmonella in meat $(96.7 \%)$ by cultural method than the present study $(40 \%)$ was reported by Malkawi and Gharaibeh, [22] and low incidence $(0,1.5,6.3,11.4$ and $20 \%)$ reported by Duffy et. al. [25], Scanga et. al. [26], Stock and Stolle [27], Heredia et. al. [28] and Hassanien et. al. [16] respectively. The incidence of S.enteritidis in mutton samples by PCR method in this study (48\%) is similar to the incidence $(47.3 \%)$ reported by Malkawi and Gharraibeh [22].

The unhygienic slaughtering methods and unhygienic environment in the sale shops of mutton might be the reasons for higher incidence of salmonellosis.

Out of 25 poutry faecal samples, 22(88\%) were positive for Salmonella by cultural method and 23(92\%) by PCR method. Out of 23 PCR positives, 17 
were positive for $S$. enteritidis by PCR, which accounts 68 and $73.9 \%$ over total number of samples and positive samples for Salmonella by PCR respectively. Low incidence $(6.9 \%$ and $50 \%)$ of Salmonella in poultry faeces by cultural method were reported by Amini et. al. [20] and Mirmomeni et. al. [29] respectively than the present study $(88 \%)$. The incidence of Salmonella (92\%) in this study by PCR method is much higher than the incidence $(1.8 \%$ and $66 \%$ ) reported by Tamuly et. al. [30] and Carli et. al. [31] respectively. The incidence (73.91) of $S$. enteritidis in poultry faeces in the present study is less than the incidence $(83.3 \%$ and $88 \%)$ reported by Salehi et. al. [32] and Mirmomeni et. al. [29] respectively and higher than the incidence (33.3\% and $51.4 \%$ ) reported by Wang et. al. [24] and Amini et. al. [20] respectively.

Out of 25 poutry cloacal samples, 21(84\%) were positive for Salmonella by cultural method and $23(92 \%)$ by PCR method. Out of 23 PCR positives, 15 were positive for $S$. enteritidis by PCR, which accounts to 60 and $65.2 \%$ over total number of samples and positive samples for Salmonella by PCR respectively. The incidence (84\%) of Salmonella in poultry cloacal samples in the present study was higher than the incidence (6.9\%) reported by Amini et. al. [20] and Eyigor et. al. [33]. The incidence of Salmonella by PCR method (92\%) was higher than the incidence (12.5\%) reported by Eyigor et. al. [33]. The incidence of S.enteritidis in poultry cloacal samples by PCR method $(65.2 \%)$ was almost similar to the incidence (62\%) reported by Eyigor et. al. [33] and higher than the incidence $(51.4 \%)$ reported by Amini et. al. [20]. Salmonella infected poultry birds will void higher levels of organisms through faeces.

Out of 10 chicken liver samples, 4(40\%) were positive for Salmonella by cultural method and $5(50 \%)$ by PCR method. Out of 5 PCR positives, 3 were positive for S.enteritidis by PCR, which accounts to $60 \%$ over positive samples for Salmonella by PCR. The incidence of Salmonella was similar in spleen and kidney at $30 \%$ and $40 \%$ by cultural and PCR methods respectively. The incidence of S.enteritidis in spleen and kidney was $50 \%$ and $75 \%$ respectively over Salmonella positive samples. Mirmomeni et. al. [29] reported that the incidence of Salmonella in chicken liver and spleen were $20 \%$ and $17 \%$ respectively by cultural method and the incidence of S.enteritidis was $90 \%$ and $73 \%$ over Salmonella positive samples.

\section{Conclusion}

High incidence of S.enteritidis was seen in most of poultry samples like chicken, kidney, liver and it's faeces than mutton, which was indicative of contamination of S.enteritidis is more prevalent in poultry farms. Based on high incidence of Salmonella and S.enteritidis in mutton and poultry related samples in and around Hyderabad, strict hygienic and sanitary procedures in rearing of livestock and poultry, slaughtering and marketing of these products should be practiced.

\section{Author's contribution}

TMR participated in the preparation of experimental design and facilities of the research. P. Ramya, carried out the entire experiment. LVR helped in the analysis of the data. TMR, LVR and PR drafted and revised the manuscript. All the authors read and approved the final manuscript.

\section{Acknowledgements}

Authors are very thankful to Sri Venkateswara Veterinary University for providing necessary infrastructure and facilities for conducting this work.

\section{Competing interests}

Authors declare that they have no competing interests.

\section{References}

1. Erdem, B., Erics, S., Hascelik, G., Gur, D. and Aysev, A.D. (2005). Antimicrobial resistance of Salmonella enteric group $C$ strains isolated from humans in Turkey, 2000-2002. Int. JAntimicrob Agents., 26:33-37.

2. National disease surveillance center. (2004). Annual Report 2003.

3. Hernandez, T., Sierra, A., Rodrigue-Alvarez, C., Torres, A., Arevalo, M.P., Calvo, M. and Arias, A. (2005). Salmonella enteric serotypes isolated from imported frozen chicken meat in the Canary Islands. $J$ Food Prot., 68(12):2702-2706.

4. Carraminana, J.J., Yanguela, J., Blanco, D., Rota, C., Agustin, A., Arino, A. and Herrera, A. (1997). Salmonella incidence and distribution of serotypes throughput processing in a Spanish poultry slaughterhouse. J Food Prot., 60:1312-1317.

5. Collighan, R.J. and Woodward, M.J. (2001). The SEF14 fimbrial antigen of Salmonella enterica serovar enteritidis is encoded within a pathogenicity islet. Vet Microbiol., 80:235-245.

6. Clayton, D.J., Bowen, A.J., Hulme, A.W., Buckley, A.M. and Deacon, V.L. (2008). Analysis of the role of 13 major fimbrial subunits in colonization of the chicken intestines by Salmonella enteric serovar enteritidis reveals a role for a novel locus. BMC Microbio., 8:228-228.

7. Gantois, I., Ducatelle, R., Pasmans, F., Haesebrouck, F. and Van Immersel, F. (2008). Salmonella enteric serovar enteritidis genes induced during oviduct colonization and egg contamination in laying hens. 
ApplEnviron Microbiol., 74:6616-6622.

8. Forshell, L.P. and Wierup, M. (2006) Salmonella contamination: A significant challenge to the global marketing of animal food products. Scientific and Technical Review of the Office International des Epizooties., 25(2):541-554.

9. Matsui, T., Suzuuki, S., Takahashi, H., Ohyama, T., kobayashi, J., Izumiya, H., Watanabe, H., Kasuga, F., Kijima, H., Shibata, K. and Okabe, N. (2004). Salmonella enteritidis outbreak associated with a school lunch dissert: cross contamination and a long incubation period, Japan, 2-1. Epidemiol Infect., 132:873-879.

10. Bennett, A.R., Greenwood, D., Tennant, C., Banks, J.G. and Betts, R.P. (1998). Rapid and definitive detection of Salmonella in foods by PCR. Lett Appl Microbiol., 26:437-441.

11. Prusak-Sochaczewski, E. and Luong, J.H.T. (1989.) An improved ELISA method for the detection of Salmonella typhimurium.JAppl Bacteriol., 66:127-135.

12. Yu, J., and Kaper, J.B. (1992). Cloning and characterization of the eae gene of enterohaemorrhagic Escherichia coli O157:H7. Mol Microbiol., 6:411-7.

13. Olsen, J.E., Aabo, S., Nielsen, E.O. and Nielsen, B.B. (1991). Isolation of a Salmonella specific DNA hybridization probe. APMIS., 99: 114-120.

14. Malorny, B., Bunge, C. and Helmuth, R. (2003). Discrimination of D-tartrate-fermenting and -nonfermenting Salmonella enteric subspp. Enteric isolates by genotypic and phenotypic methods. $J$. Clin. Microbiol., 41: 4292-4297.

15. Pan, T.M. and Liu, Y.J. (2002). Identification of Salmonella enteritidis isolates by polymerase chain reaction and multiplex polymerase chain reaction. $J$. Microbiol. Immunol. Infect., 35: 147-151

16. Hassanien, R., Hassan Ali, S.F., El-Malek, A.M.A, MoemenMohamed, A., Elsayh, K.I. (2011). Detection and identification of Salmonella species in minced beef and chicken meats by using multiplex PCR in assiut city. Vet World., 4(1):5-11.

17. Tavechio, N.T. (2002). Salmonella serotypes isolated from nonhuman sources in Sao Paulo, Brazil, from 1996 through 2000. J Food Prot., 65(6): 1041-1044.

18. Plummer, R.A.S., Blisset, S.J., Dodd, C.E.R. (1995). Salmonella contamination of retail chicken products sold in the U.K. J Food Prot., 58:843-846.

19. Cortez, A.L.L., Carvalho, A.C.F.B., Ikuno, A.A., Burger, K.P. and Vidal-Martins, A.M.C. (2006). Identification of Salmonella spp. isolates from chicken abattoirs by multiplex-PCR. Res Vet Sci., 81:340-344.

20. Amini, K., Salehi, T.Z., Nikbakht, G., Ranjbar, R., Amini, J. and Ashrafganjooei, S.B. (2010). Molecular detection of invA and $s p v$ virulence genes in Salmonella enteritiis isolated from human and animals in Iran. African J Microbiol Research., 4(21):2202-2210.

21. Blivet, D., Salvat, G., Humbert, F. and Colin, P.
(1998). Development of a new culture medium for the rapid detection of Salmonella by indirect conductance measurements. JApll Microbiol., 84:399-403.

22. Malkawi, H.I., and Gharaibeh, R. (2004). Rapid and simultaneous Identification of Two Salmonella enteric serotypes, enteritidis and typhimurium from chicken and meat products by multiplex PCR. Biotechnology., 3(1):44-48.

23. Uyttendaele, M., de Troy, P. and Debevere, J. (1999). Incidence of Salmonella, Campylobacter jejuni, Campylobacter coli, and Listeria monocytogenes in Poultry Carcasses and Different Types of Poultry Products for Sale on the Belgian Retail Market . J Food Prot., 62(7):735-740.

24. Wang, S.J., Yeh, D.B., Wei, C. (2009). Specific PCR primers for the identification of Salmonella enteric serovar enteritidis in chicken related samples. J Food and Drug Analysis., 17(3):183-189.

25. Duffy, G., Cloak, O.M., Osullivan, M.G., Guillet, A., Sheridan, J.J., Blair, I.S. and McDowell, D.A. (1999) The incidence and antibiotic resistance profiles of Salmonella spp. on Irish retail meat products. Food Microbiol., 16:623-631.

26. Scanga, J.A., Bellinger, G.R., Belk, K.E. and Smith, G.C. (1999). A microbiological profile of domestic and imported beef raw materials distended for use in ground beef production. Beef Program report, Department of Animal Sciences, Colorado State Univ.

27. Stock, K. and Stolle, A. (2001). Incidence of Salmonella in minced meat produced in a Eropean Union approved cutting plant. J Food Prot., 64 (9): 1435-1438.

28. Heredia, N., Garcia, S., Rojas, G., Salazar, L. (2001). Microbiological condition of ground meat retailed in Monterrey, Mexico. J Food Prot., 64(8):1249-1251.

29. Mirmomeni, M.H., Naderi, S., Hosseinzadeh colagar, A. and Sisakhtnezhad, S. (2009). Isolation of Salmonella enteritidis using biochemical tests and diagnostic potential of $S d f I$ amplified gene. Research J Biological Sci., 4(6):656-661.

30. Tamuly, S., Saxena, M.K., Ambwani, T. and Lakhchaura, B.D. (2008). Rapid detection of Salmonella from poultry faecal samples using PCR targeting invA gene. Indian Vet J., 85:919-920.

31. Carli, K.T., Unal, C.B., Caner, V. and Eyigor, A. (2001). Detection of Salmonellae in chicken faeces by a combination of tetrathionate broth enrichment, capillary PCR, and capillary gel electrophoresis. $J$. Clin. Microbiol., 39(5):1871-1876.

32. Salehi, T.Z., Madadgar, O., Naserli, S., Fasaei, B.N., Ghafari, M.M. and Tamai, I.A. (2011). Detection of sef14, sef17 and sef21 fimbrial virulence genes of Salmonella enteritidis by multiplex PCR. J Animal and Vet Advances., 10(11):1421-1426.

33. Eyigor, A., Carli, K.T. and Unal, C.B. (2002). Implementation of real-time PCR to tetrathionate broth enrichment step of Salmonella detection in poultry. Lett Appl Microbiol., 34(1):37-41.

$* * *$ 